\title{
Article III and the Westfall Act: Identifying "Federal Ingredients"
}

\author{
Sandra Slack Glover $\dagger$
}

The constitutional language is deceptively simple: the federal judicial power "shall extend to all Cases . . . arising under" federal law. ${ }^{1}$ These words grant federal courts the constitutional authority to decide cases involving federal laws passed by Congress. Yet the simplicity of this constitutional grant of "arising under" jurisdiction has spawned a debate throughout the nation's history: What, if any, are the limits on Congress's power to create federal jurisdiction under this clause of Article III? Can Congress confer federal jurisdiction merely by passing a jurisdictional statute, so that a case arises under a federal law even if that law merely grants jurisdiction to the federal courts? Or must there be a "substantive" federal law-something more than a jurisdictional grant-for the case to arise under federal law? Supreme Court cases that test the limits of arising under jurisdiction are rare, and in the few opportunities the Supreme Court has had to define those limits, it has declined to do so. ${ }^{2}$

But when those cases do arise, the meaning of the words "arising under" assumes special significance. Do those words limit congressional power to create federal jurisdiction? If so, what are the limits embedded in those words? The significance of this constitutional issue becomes clear in its application to the Federal Employees Liability Reform and Tort Compensation Act, ${ }^{3}$ known as the "Westfall Act." The Westfall Act relieves federal employees

$\dagger$ B.A. 1992, The University of Virginia; M.A. 1993, Duke University; J.D. Candidate 1997, The University of Chicago.

1 US Const, Art III, $\$ 2$ (emphasis added).

2 See Mesa v California, 489 US 121, 136-37 (1989) (adopting an interpretation of the federal officer removal statute to avoid a reading that would raise constitutional doubt about federal jurisdiction); Verlinden B.V. $v$ Central Bank of Nigeria, 461 US 480, 493 (1983) ("We need not . . . decide the precise boundaries of Art. III jurisdiction, however, since the present case . . . clearly 'arises under' federal law, as that term is used in Art. III."). Although the Supreme Court has decided cases that limit the statutory grant of arising under jurisdiction, see, for example, Louisville \& Nashville Railroad Co v Mottley, 211 US 149 (1908) (requiring that the federal element appear on the face of a well pleaded complaint), statutory limits on which cases arise under federal law do not determine the scope of the constitutional grant. See Verlinden, 461 US at 495 (noting that limits on the federal jurisdictional statute, 28 USC $\$ 1331$ (1994), do not limit congressional power to grant jurisdiction under the Constitution and that "Art. III 'arising under' jurisdiction is broader than federal-question jurisdiction under $\$ 1331$...." (citations omitted)).

${ }^{3} 28$ USC $\$ 2679$ (1994). 
of liability for the consequences of any tortious acts they commit while acting within the scope of their employment by substituting the United States government as the defendant, in place of the employee. ${ }^{4}$ The constitutional issue arises when federal courts proceed to adjudicate such tort suits even after they determine that the employee was not acting within the scope of her employment: Does Congress have the constitutional authority to extend federal jurisdiction to state law tort claims between non-diverse parties when one of the parties happens to be a federal employee?

This Comment explores the boundaries of Article III arising under jurisdiction in the context of the Westfall Act. Although the Supreme Court's Article III jurisprudence establishes that a case must contain a "federal ingredient" to arise under federal law within the meaning of Article III, ${ }^{5}$ the Court also has established that not every federal issue is sufficient to qualify as a federal ingredient. For example, although purely jurisdictional statutes are federal laws and raise issues of statutory interpretation, they cannot sustain Article III arising under jurisdiction. However, the Court's caselaw does not draw a definitive line for determining when a federal issue is more than jurisdictional-that is, when it is sufficiently substantive - to qualify as a federal ingredient.

This Comment suggests a functional test for drawing the line between purely jurisdictional federal issues and federal ingredients, thus solving the constitutional dilemma posed by the Westfall Act. According to this test, a federal law is sufficiently substantive to qualify as a federal ingredient if it establishes a rule that must be applied in federal courts and in state courts. In other words, if a state court with jurisdiction over a case would have to apply federal law to decide the case, the federal law qualifies as a federal ingredient. This test draws a line between "substantive" and "jurisdictional" statutes without reliance on the arbitrary labels attached to particular statutes. Because the Westfall Act does not apply in state courts, it is not sufficiently substantive to qualify as a federal ingredient.

To provide a context for this new test, Part I of this Comment describes the Westfall Act and the constitutional dilemma it poses. Part II then explores the Supreme Court's jurisprudence on Article III, and resolves the constitutional dilemma by concluding that a federal law is sufficient to sustain federal jurisdiction when that federal law must be applied by both federal and state courts. Under this test, the Westfall Act cannot sustain federal jurisdic-

\footnotetext{
4 See Part I.A.

s See the discussion of these issues in Part II.
} 
tion because state courts do not have to apply federal law to resolve cases under the Westfall Act. Part III finds support for this proposed doctrinal distinction through a review of the major rationales for arising under jurisdiction. Part IV considers and rejects an alternative analysis, suggested by Justice Ginsburg, that supplemental jurisdiction provides an analogy to sustain the jurisdictional grant under the Westfall Act. Finally, this Comment concludes that, because the Westfall Act extends federal jurisdiction to cases beyond the limits defined by Article III, courts should interpret the Westfall Act to require remand to state courts of those cases that, left in federal court, would require the federal court to adjudicate a case that did not arise under federal law.

\section{The WestFall Act AND the CONSTitutional PROBLEM}

\section{A. The Westfall Act}

The Federal Tort Claims Act ("FTCA") waives federal sovereign immunity for torts committed by federal employees. Under the FTCA, the United States is liable-subject to certain exceptions ${ }^{7}$-for all torts committed by federal employees acting within the scope of their employment. ${ }^{8}$ The Westfall Act amended the FTCA to provide that the remedy against the United States under the FTCA is the exclusive remedy for torts committed by government employees. ${ }^{9}$ In other words, the Westfall Act confers absolute immunity upon federal employees for torts committed within the scope of their employment. ${ }^{10}$ In United States $v$ Smith, the Su-

- 28 USC $\S \S 1346(b), 2671-80$ (1994).

7 See 28 USC $\$ 2680$ (1994) (listing exceptions to governmental liability under the FTCA).

28 USC \$ 1346(b). See generally Richard H. Fallon, Daniel J. Meltzer, and David L. Shapiro, Hart and Wechsler's The Federal Courts and the Federal System 1030-36 (Foundation 4th ed 1996) (describing the FTCA).

${ }^{9}$ See 28 USC \& 2679(b)(1) (1994) ("The remedy against the United States [under the FTCA] is exclusive of any other civil action or proceeding for money damages by reason of the same subject matter...."). See also Fallon, Meltzer, and Shapiro, Federal Courts and the Federal System at $1030 \mathrm{n} 10$ (cited in note 8) (describing the purpose of the Westfall Act).

${ }^{10}$ See United States $v$ Smith, 499 US 160, 163 (1991). The Westfall Act was a direct response to the Supreme Court's decision in Westfall v Erwin, 484 US 292 (1988), which had limited the doctrine of official immunity for federal employees. See Federal Employees Liability Reform and Tort Compensation Act of 1988, Pub L No 100-694, 102 Stat 4563 $\$ 2$ (a)(4) (citing Westfall as impetus for the Act). For an overview of federal employee immunities and the history of the Westfall Act, see generally William T. Cornell, Note, An Evaluation of The Federal Employees Liability Reform and Tort Compensation Act: Congress' Response to Westfall v. Erwin, 26 San Diego L Rev 137, 138-47 (1989); Daniel A. Morris, Federal Employees' Liability Since the Federal Employees Liability Reform \& Tort Compensation Act of 1988 (The Westfall Act), 25 Creighton L Rev 73, 73-82 (1991). 
preme Court confirmed that the Westfall Act immunizes employees from liability even when an exception in the FTCA precludes a suit against the government. ${ }^{11}$ Thus, in cases brought under the FTCA for torts committed by employees in the scope of their employment, the United States is the sole defendant.

To create this exclusive liability of the United States under the FTCA, the Westfall Act establishes procedures for transforming a tort suit against a federal employee into a suit against the United States under the FTCA if the employee was acting within the scope of her employment when the tortious act occurred. There are four possible procedures. First, when an action is filed in federal district court, the Attorney General ${ }^{12}$ can certify that the employee acted within the scope of her employment. Upon such certification, the action is deemed to be against the United States under the FTCA and the United States is substituted as the defendant. ${ }^{13}$ Second, when the action is filed in state court and the Attorney General certifies that the employee acted within the scope of her employment, the Attorney General must remove the action to federal court, where it proceeds against the United States under the FTCA. ${ }^{14}$

The other two procedures for transforming a suit into a case against the United States arise if the Attorney General refuses to certify that the employee acted within the scope of her employment. The employee then may challenge the Attorney General's decision by petitioning the court to find that she did act within the scope of her employment. ${ }^{15}$ If the action is filed in federal court, and the court certifies that the employee acted within the scope of her employment, thus overruling the Attorney General's decision, the matter proceeds as it would have if the Attorney General had originally certified the issue. ${ }^{16}$ Alternatively, if the employee challenges the Attorney General's decision in a case originally filed in state court, the Attorney General may remove the action to federal court for consideration of the employee's petition. If the federal court determines that the employee acted within the scope of her employment, the matter proceeds as if the Attorney General had made the initial certification. However, after removal, if the court determines that the employee was not

"11 499 US 160, 166 (1991).

${ }^{12}$ The Attorney General has delegated this decision to local United States Attorneys. $28 \mathrm{CFR} \S 15.3(\mathrm{a})$ (1996). For simplicity and for consistency with the statutory language, this Comment will refer to the Attorney General as the final decision maker.

${ }^{13} 28$ USC $\$ 2679$ (d)(1) (1994).

${ }^{14} 28$ USC $\$ 2679$ (d)(2) (1994).

${ }^{25} 28$ USC $\$ 2679(\mathrm{~d})(3)(1994)$.

${ }^{16} \mathrm{Id}$. 
acting within the scope of her employment, the case "shall be remanded to the State court."17 These procedures insure that suits for alleged torts committed by federal employees acting within the scope of their employment are prosecuted against the United States in federal court.

Although the Westfall Act provides a procedure for the employee-defendant to challenge an adverse decision by the Attorney General on scope of employment, ${ }^{18}$ the Act does not establish a parallel procedure for the plaintiff to challenge the Attorney General's decision certifying that the defendant acted within the scope of her employment. In many cases, a plaintiff will not challenge the Attorney General's decision because she will prefer to litigate against the United States, rather than against a potentially judgment-proof federal employee. However, for other plaintiffs, a suit against the United States under the FTCA will be unattractive, since the FTCA may act as a complete bar to recovery. ${ }^{19} \mathrm{Un}$ der the FTCA, the United States has consented to suit for certain activities, but the consent is subject to certain listed exceptions. ${ }^{20}$ If the plaintiff's claim falls within an exception, the plaintiff may not recover against the United States since the government has not consented to suit. Moreover, since the FTCA is the exclusive remedy for torts committed by federal employees who acted within the scope of their employment, the plaintiff may not recover against the federal employee. ${ }^{21}$ Thus, in some cases, plaintiffs may wish to challenge a certification to avoid prosecuting a claim against the United States. In sum, although some plaintiffs will be displeased with the Attorney General's decision that the defendant-employee acted within the scope of her employment, the Westfall Act does not provide a statutory mechanism for a plaintiff to initiate a review of this decision. The Westfall Act's

${ }^{17}$ Id.

${ }^{18}$ Id.

${ }^{13}$ The FTCA has other features that make it unattractive for some plaintiffs. For example, the FTCA does not allow punitive damages, see 28 USC $\$ 2674$ (1994), or jury trials in claims against the United States, see rcHugh $v$ University of Vermont, $966 \mathrm{~F} 2 \mathrm{~d}$ 67, 71 (2d Cir 1992).

${ }^{2}$ See 28 USC $\$ 2680$. For example, the United States cannot be sued for intentional torts such as assault, battery, and libel. 28 USC $\$ 2680(\mathrm{~h})$ (1994). See Nasuti v Scannell, 906 F2d 802, 814 (1st Cir 1990) (rejecting a claim alleging assault and battery); Meridian International Logistics, Inc $v$ United States, 939 F2d 740, 742-43 (9th Cir 1991) (rejecting a claim alleging libel and slander). Similarly, the United States has not consented to being sued for claims arising in a foreign country. 28 USC $\$ 2680(\mathrm{k})$ (1994). See Gutierrez de Martinez $v$ Lamagno, $115 \mathrm{~S}$ Ct 2227, 2230 (1995) (noting that if the United States were substituted as defendant, the plaintiff's' claim would be barred by the FTCA because the claim arose in Colombia).

${ }^{21}$ See Smith, 499 US at 165 . See also text accompanying notes 9-11. 
silence on this issue-the reviewability of the Attorney General's scope certification-set the stage for Gutierrez de Martinez $v$ Lamagno. ${ }^{22}$

\section{B. Lamagno and the Constitutional Problem}

After the passage of the Westfall Act, the courts were divided over whether they could review the Attorney General's certification that the employee acted within the scope of employment. ${ }^{23}$ In Lamagno, the Supreme Court held that federal courts can review the Attorney General's certification that a federal employee acted within the scope of his employment. ${ }^{24}$

The Supreme Court's resolution of the reviewability dispute poses a new question: is there federal jurisdiction if the district court decides that the employee did not act within the scope of employment? ${ }^{25}$ Once the district court rejects the Attorney General's certification, the individual employee is reinstated as the defendant. At this point, the federal court may be left with a state common law tort action between non-diverse parties. The Supreme Court did not decide whether the federal court then has subject matter jurisdiction over the remaining state law tort claim, or must instead remand the action to state court.

This jurisdictional dilemma requires an interpretation of both the Westfall Act and Article III of the Constitution. Although the circuit courts have disagreed about the proper interpretation of the Westfall Act, ${ }^{26}$ eight Justices in Lamagno seemed to agree that the statute requires a federal court to retain the state law claims even after the court concludes that the employee did not act within the scope of employment. ${ }^{27}$ Despite their agreement on

${ }^{22} 115$ S Ct 2227 (1995).

${ }^{23}$ Compare Johnson v Carter, 983 F2d 1316, 1319-21 (4th Cir 1993) (en banc) (finding certification not reviewable), with Nasuti $v$ Scannel, 906 F2d 802, 812-14 (1st Cir 1990) (finding certification reviewable). See Lamagno, $115 \mathrm{~S} \mathrm{Ct}$ at $2230 \mathrm{n} 3$ (collecting cases). The question of reviewability arises only when the plaintiff challenges a certification that the employee acted within the scope of employment; the Westfall Act contains specific procedures for a defendant-employee to challenge an adverse decision by the Attorney General. 28 USC \$ 2679(d)(3). See text accompanying notes 15-22.

24 $115 \mathrm{~S}$ Ct at 2231-36.

${ }^{25}$ This question arose pre-Lamagno in courts that had interpreted the Westfall Act to allow judicial review of the scope certification. See, for example, Nasuti, 906 F2d at 814 $\mathrm{n}$ 17; Aliota $v$ Graham, 984 F2d 1350, 1356 (3d Cir 1993). Because of the holding in Lamagno, however, the question is relevant for all courts.

${ }^{25}$ See, for example, Haddon $v$ United States, 68 F3d 1420, 1427 (DC Cir 1995) (interpreting the Westfall Act to require federal courts to remand the action to a state court once the United States is removed from the action); Nasuti, 906 F2d at $814 \mathrm{n} 17$ (same); Aliota, $984 \mathrm{~F} 2 \mathrm{~d}$ at 1356 (interpreting the Westfall Act to require federal courts to retain the case once it is removed); Garcia v United States, 88 F3d 318, 325 (5th Cir 1996) (same).

${ }^{27}$ Lamagno, $115 \mathrm{~S}$ Ct at 2236 (Ginsburg, Stevens, Kennedy, and Breyer); id at 2239 
the interpretation of the statute, the Justices were divided over the Article III problems raised by this statutory requirement. If the statute requires federal courts to retain the state law tort claims, is this statute consistent with Article III's grant of federal judicial power? Writing for a plurality, ${ }^{28}$ Justice Ginsburg addressed this point by stating that the retention of jurisdiction over non-diverse state law claims presented no "grave" Article III problem. ${ }^{29}$ In contrast, Justice Souter argued in his dissent that retaining federal jurisdiction "approach[ed] the limit" of Article III jurisdiction, if it did not exceed that limit. ${ }^{30}$

Justice Souter dissented from the conclusion that the Attorney General's certification is reviewable primarily because he thought the Court should interpret the Westfall Act to avoid constitutionally questionable jurisdictional decisions. ${ }^{31}$ According to Souter, allowing judicial review raises a serious Article III question when the court rejects the Attorney General's certification. Souter argued that it is the substitution of the United States as a defendant that establishes arising under jurisdiction, and that this substitution depends on the scope of employment certification. Therefore, the

challenge to the certification is [ ] the equivalent of a challenge to the essential jurisdictional fact that the United States is a party, and the federal court's jurisdiction to review scope of employment (on the Court's theory) is merely an example of any court's necessary authority to rule on a challenge to its own jurisdiction to try a particular action. ${ }^{32}$

Accordingly, the plurality's contention that the court's review of the certification provides the basis for federal jurisdiction is equivalent to "saying the authority to determine whether a Court has jurisdiction over the cause of action supplies the very jurisdiction that is subject to challenge."33

Justice Ginsburg dismissed Justice Souter's Article III con-

(Souter dissenting, joined by Rehnquist, Scalia, and Thomas). As Justice O'Connor noted in her concurring opinion, the constitutional issue was not presented by the case before the court; the arguments on the issue are thus dicta. Id at 2237 (O'Connor concurring).

$\approx$ Justice Ginsburg wrote for only four members of the Court on this point. Justice O'Connor refused to join this part of the opinion because "[t]hat discussion all but conclusively resolves a difficult question of federal jurisdiction that, as the Court notes, is not presented in this case." Id at 2237. (O'Connor concurring).

2 Id at 2236 (Ginsburg plurality opinion).

$\Rightarrow$ Id at 2239 (Souter dissenting).

31 Id.

Id at 2240 .

${ }^{3} \mathrm{Id}$. 
cerns as "abstract and unrelenting. ${ }^{34}$ According to Ginsburg, the Attorney General's certification presents a non-frivolous federal question-whether the employee acted within the scope of employment-to be reviewed in federal court at the outset of the litigation. ${ }^{35}$ Through an analogy to supplemental jurisdiction, Ginsburg then posited that once the federal court has resolved the scope of employment question, "[c]onsiderations of judicial economy, convenience and fairness to litigants" argue for the court to decide the remaining issues in the case. ${ }^{36}$

Thus, while Lamagno resolves an issue of statutory interpretation, it creates a constitutional quagmire. By holding that the Attorney General's decision is reviewable, and by apparently interpreting the Westfall Act to require federal courts to retain jurisdiction even when they determine that the employee did not act within the scope of employment, ${ }^{37}$ Lamagno forces all courts to face the constitutional question lurking in the Westfall Act. Does Congress have the constitutional authority to require federal courts to hear state law tort claims between non-diverse parties? More specifically, under the Westfall Act, is review of the Attorney General's certification a sufficient federal ingredient to support arising under jurisdiction, or does review of the certification merely resolve whether federal jurisdiction exists?

\section{Lower Court Interpretations of the Constitutional Issue}

This constitutional question has been addressed by two federal appellate courts since the Supreme Court raised the issue in Lamagno. Both of these courts relied heavily on the Supreme Court's opinion in Lamagno, but neither court advanced any original arguments to resolve the constitutional dilemma. In Garcia $v$ United States, the Fifth Circuit held that requiring federal courts to retain Westfall Act cases even after the court rejected the Attorney General's certification is consistent with Article III. ${ }^{38}$

${ }^{34}$ Id at 2237 n 11 (Ginsburg plurality opinion).

${ }^{35}$ Id at 2236-37 ("Because a case under the Westfall Act thus 'raises [a] questio[n] of substantive federal law at the very outset,' it 'clearly "arises under" federal law, as that term is used in Art. III.") (brackets in original) (internal citation omitted), citing Verlinden B.V. $v$ Central Bank of Nigeria, 461 US 480, 493 (1983).

${ }^{35}$ Lamagno, 115 S Ct at 2237, quoting United Mine Workers $v$ Gibbs, 383 US 715, 726 (1966).

${ }^{37}$ See note 27 . Two caveats are in order. First, the statutory issue was not squarely presented to the Court. See Lamagno, $115 \mathrm{~S} \mathrm{Ct}$ at 2237 (O'Connor concurring). Second, the D.C. Circuit has offered a plausible interpretation of the statute, post-Lamagno, that requires remand to state court. See Haddon, 68 F3d at 1427. However, it seems that eight Justices have no disagreement about the interpretation of the statute.

${ }^{33} 88$ F3d 318, 325 (5th Cir 1996). 
Citing Justice Ginsburg's plurality with approval, the court held that the Attorney General's certification is an "initial colorable federal question," and that considerations of judicial economy support the retention of jurisdiction in these cases. ${ }^{39}$

In contrast, the D.C. Circuit invoked constitutional concerns to support its holding that a court must remand these actions. In Haddon $v$ United States, the court held that by interpreting the Westfall Act to require remand, the court avoids potential constitutional questions about the scope of Article III arising under jurisdiction: "Permitting a federal court to retain a case after determining that no federal issue or diversity of citizenship exists would ... potentially raise serious questions regarding Article III jurisdiction." courts are obligated to interpret statutes to avoid constitutional issues, this obligation "does not mean we should misconstrue a statute in order to avoid the constitutional question." ${ }^{\text {"41 }}$ Judge Sentelle did not offer his view on the constitutional question, though, because the majority's resolution of the statute obviated the need to decide the question. ${ }^{42}$ Thus, the divide in the lower courts over the constitutional question posed by the Westfall Act mirrors the divide in the Supreme Court. The federal courts have been unable to agree on the proper resolution of the Westfall Act's constitutional quagmire because the doctrinal test for defining the limits of Article III arising under jurisdiction does not resolve the issue.

\section{ARTICLE III ARISING UNDER JURISDICTION: FEDERAL INGREDIENTS}

\section{A. Osborn's Federal Ingredient Test}

The confusion over the scope of Article III arising under jurisdiction began long before Congress drafted the Westfall Act. The Court first interpreted the constitutional clause in Osborn $v$ Bank of the United States. ${ }^{43}$ In Osborn, the Bank of the United States sought to enjoin the enforcement of an allegedly unconsti-

\footnotetext{
39 Id. Two district courts have noted the constitutional issue in passing but have avoided deciding the issue. See Wilson $v$ Jones, 902 F Supp 673, 678 n 2 (E D Va 1995) (noting that the issue was not raised in the case, but mentioning in dicta that a plurality in Lamagno had suggested that the decision on scope of employment presents a non-frivolous federal question at outset of litigation); Whytosek $v$ Rademan, 903 F Supp 842, 845 n 4 (E D $\mathrm{Pa}$ 1995) (noting that Souter's dissent in Lamagno raised a constitutional issue, but avoiding further discussion of the issue).

${ }^{40} 68$ F3d 1420, 1427 (DC Cir 1995).

${ }^{41}$ Id at 1428 (Sentelle dissenting).

42 Id.

22 US (9 Wheat) 738 (1824).
} 
tutional state tax levied on the Bank by the state of Ohio. ${ }^{44}$ Chief Justice Marshall held that the Bank's charter gave federal courts jurisdiction over the suit, ${ }^{45}$ and then upheld this statutory charter as a constitutional grant of jurisdiction:

We think, then, that when a question to which the judicial power of the Union is extended by the constitution, forms an ingredient of the original cause, it is in the power of Congress to give the Circuit Courts jurisdiction of that cause . . . .46

Thus, Chief Justice Marshall's opinion in Osborn established the basic doctrinal test for Article III jurisdiction: to arise under federal law, a case must contain a "federal ingredient." In other words, Article III allows Congress to confer federal jurisdiction whenever a case or controversy contains a federal ingredient. ${ }^{47}$ The federal ingredient in Osborn was the federal law that established the Bank and empowered it to act. Every case involving the Bank contained, as an original component, a determination of whether the Bank had been granted the power to act by federal law. ${ }^{48}$ Osborn's federal ingredient doctrinal test has been explicitly reaffirmed throughout the nation's history. ${ }^{49}$

Osborn's federal ingredient test, though, cannot be the complete test. The Court has never held that every federal issue in a case is sufficient to satisfy the federal ingredient test. In other words, some federal issues are Article III federal ingredients, but others are not. "Federal ingredient" is a term of art. If any federal issue satisfied Osborn's federal ingredient test, there would be no limits on Congress's power to create federal jurisdiction because

"Id at 739-40.

${ }^{4}$ Id at $817-18$.

"s Id at 823.

${ }^{47}$ David P. Currie, The Federal Courts and the American Law Institute (Part II), $36 \mathrm{U}$ Chi L Rev 268, 268-69 (1969). Others have interpreted Osborn to authorize federal judicial power whenever there is a potential federal ingredient in the case. See, for example, Erwin Chemerinsky, Federal Jurisdiction \$ 5.2 at 226-27 (Little, Brown 1989). See also Verlinden B.V. $v$ Central Bank of Nigeria, 461 US 480, 492 (1983) (noting that Osborn seems to allow federal jurisdiction whenever a "case or controversy [ ] might call for the application of federal law" but also noting that "[ $t]$ he breadth of that conclusion has been questioned").

${ }^{4}$ Osborn, 22 US (9 Wheat) at 823-25. Osborn itself was actually an easy case, since the constitutionality of a state tax on the Bank clearly arises under the Constitution. The harder case would arise when the Bank litigated a purely state law matter, such as a contract. Marshall addressed this hypothetical in Osborn. According to Marshall, when the Bank sued (or was sued) on a contract, the first question in every case was whether the Bank had a right to make the contract. That question was a matter of federal law because federal law gave the Bank the power to act. Id at 823-24. In a companion case, Bank of the United States v Planters' Bank, the Supreme Court confirmed this dicta, citing Osborn for the proposition that a suit by the Bank against a state bank on negotiable notes was sufficient to confer federal jurisdiction. 22 US (9 Wheat) 904, 904-05 (1824).

${ }^{*}$ See, most recently, Verlinden, 461 US at 492-93. 
Congress could insert a federal issue into every case by enacting a jurisdictional statute. For example, Congress could enact the following statute: "Federal courts shall have original jurisdiction over all tort cases." This statute would create a federal issue: the jurisdiction of the federal courts. If any federal issue satisfied the Osborn test, the grant would be constitutional. Thus, the example demonstrates that, in order to establish limits on Congress's power to extend jurisdiction, not every federal issue can satisfy Osborn's federal ingredient test.

The language of Article III establishes that there are inherent limits on congressional power to create federal jurisdiction. Article III extends the federal judicial power to only nine defined heads of jurisdiction. ${ }^{50}$ This enumeration of judicial power serves as a limit on the exercise of federal jurisdiction, and argues against the notion that the Framers intended to confer broader authority. The Federalist Papers provide additional support for this interpretation of the language:

[T] he judicial authority of the federal judicatures is declared by the Constitution to comprehend certain cases particularly specified. The expression of those cases marks the precise limits beyond which the federal courts cannot extend their jurisdiction, because the objects of their cognizance being enumerated, the specification would be nugatory if it did not exclude all ideas of more extensive authority. ${ }^{51}$

The enumerated grant of authority in Article III was part of an explicit compromise regarding the extent of federal power. The limits on the exercise of federal judicial power protect the states from federal usurpation of all judicial power. The limits thus protect the autonomy and authority of states and their court systems within the federal system. ${ }^{52}$ Article III thus reflects the constitutional principle of federalism.

In order to respect the principles of federalism in the text and history of Article III, the Supreme Court has made clear that not all federal issues are federal ingredients. Specifically, the Court has held that purely jurisdictional statutes, although technically federal laws and therefore federal issues, do not qualify as federal ingredients. ${ }^{53}$ In other words, only non-jurisdictional federal is-

\footnotetext{
${ }^{6}$ US Const, Art III, § 2.

${ }^{61}$ Federalist 83 (Hamilton), in Clinton Rossiter, ed, The Federalist Papers 495, 497 (New American Library 1961).

${ }^{52}$ See Martin H. Redish, Federal Jurisdiction: Tensions in the Allocation of Judicial Power 62 (Bobbs-Merrill 1980).

${ }^{{ }^{33}}$ See The Propeller Genesee Chief $v$ Fitzhugh, 53 US (12 How) 443, $451-53$ (1851); Mossman $v$ Higginson, 4 US (4 Dall) 12, 14 (1800) (holding that Congress cannot confer ju-
} 
sues qualify as federal ingredients. If the only federal issue is the interpretation of a statute granting federal jurisdiction, this federal issue cannot bootstrap a case into federal court.

Consider a familiar jurisdictional statute, $\S 1332$, which grants federal courts jurisdiction over diversity cases. ${ }^{54}$ To establish subject matter jurisdiction under $\S 1332$, a federal court must apply federal standards governing "citizenship" and "domicile" to determine whether the parties are diverse.$^{55}$ If the court finds that the parties are not diverse, the case is dismissed for lack of subject matter jurisdiction. ${ }^{56}$ The application of federal standards to determine domicile or citizenship under $\S 1332$ does not qualify as a federal ingredient, though these are federal issues. If the mere interpretation of the diversity statute qualified as a federal ingredient, then all cases could be brought in federal court for a decision about the presence or absence of diversity, and thus they would arise under the diversity statute because courts would have to interpret the statute even when the parties were not diverse. In summary, although federal courts have the power to determine their own jurisdiction, ${ }^{57}$ the power to interpret and apply jurisdictional statutes does not constitute a federal ingredient sufficient in itself to sustain the exercise of federal judicial power.

\section{B. Identifying Federal Ingredients}

1. Deriving the test.

Often, the line between substantive and jurisdictional federal issues is clear. Broadly, jurisdictional issues are preliminary questions that define the power of the court to hear the case, ${ }^{58}$ whereas substantive issues are the rules of decision that govern the resolution of the merits of the case. ${ }^{59}$ But not all issues are

risdiction merely by passing a jurisdictional statute). See also Verlinden, 461 US at 495-97 (upholding constitutionality of statute in contrast to other statutes that had been found unconstitutional because they "sought to do nothing more than grant jurisdiction over a particular class of cases"); Mesa v California, 489 US 121, 136 (1989) (describing a statute as purely jurisdictional and concluding that "therefore, [it] cannot independently support Art. IIII 'arising under' jurisdiction").

${ }^{54} 28$ USC \& 1332 (1994).

${ }^{s 5}$ See, for example, Sadat v Mertes, 615 F2d 1176, 1180 (7th Cir 1980).

${ }^{5 s}$ See id at 1187, 1189 (upholding dismissal for lack of subject matter jurisdiction after determining that parties were not diverse within the meaning of the statute).

${ }^{57}$ See Lamagno, $115 \mathrm{~S} \mathrm{Ct}$ at 2240 (Souter dissenting). See also Shannon $v$ Shannon, 965 F2d 542, 545 (7th Cir 1992) ("[F] ederal courts have jurisdiction to determine whether they have subject matter jurisdiction."); Charles Alan Wright, Arthur R. Miller, Edward H. Cooper, 13A Federal Practice and Procedure: Jurisdiction $\$ 3536$ (West 2d ed 1984).

${ }^{6}$ See, for example, the diversity jurisdiction statute, 28 USC $\$ 1332$.

${ }^{59}$ Consider the Sherman Antitrust Act, 15 USC $\$ 11$ et seq (1994) (declaring illegal every contract or conspiracy in restraint of trade or commerce). 
easily classified as "substantive" or "jurisdictional." When a statute is not easily classified as either jurisdictional or substantive, courts need a method to determine when the statute is sufficiently substantive to qualify as a federal ingredient. The Supreme Court's analysis of the Foreign Sovereign Immunities Act ${ }^{60}$ ("FSIA") in Verlinden B.V. $v$ Central Bank of Nigeria ${ }^{61}$ provides some guidance.

In Verlinden, the Supreme Court faced a statute that has both substantive and jurisdictional components. ${ }^{62}$ The FSIA codifies substantive standards for identifying when a foreign sovereign is immune from suit in the United States, ${ }^{63}$ but it also explicitly provides that the result of this inquiry into sovereign immunity determines subject matter jurisdiction. ${ }^{64}$ The Supreme Court had to determine whether the inquiry into sovereign immunity-an inquiry into jurisdiction and substance-could sustain Article III arising under jurisdiction. The Court held that sovereign immunity is sufficiently substantive to qualify as a federal ingredient and to sustain Article III arising under jurisdiction. ${ }^{65}$

Although sovereign immunity under the FSIA combines substantive and jurisdictional questions, all jurisdictional statutes incorporate similar elements of substance into the jurisdictional inquiry, but they are not all sufficiently substantive to sustain Article III arising under jurisdiction. ${ }^{66}$ For example, federal standards governing whether a party is a citizen have jurisdictional consequences under the diversity statute. But the mere presence of federal standards does not mean that all cases arise under federal law. A doctrinal test for Article III arising under jurisdiction must be able to explain why the inquiry into sovereign immunity under the FSIA qualifies as a federal ingredient while the inquiry

${ }^{6}$ Foreign Sovereign Immunities Act of 1976, 28 USC $\S \S 1330,1602-1611$ (1994). See generally Foreign Sovereign Immunities Act of 1976, HR Rep No 94-1487, 94th Cong, 2d Sess, reprinted in 1976 USCCAN 6604; Mary Kay Kane, Suing Foreign Sovereigns: A Procedural Compass, 34 Stan L Rev 385 (1982) (describing the FSIA).

${ }^{6} 461$ US 480, 491-97 (1983).

${ }^{2}$ The Supreme Court focused only on the provisions of the FSIA labeled "jurisdictional." However, the FSIA also establishes standards of liability for foreign sovereigns. See 28 USC $\$ 1606$ (1994). Arguably, this substantive liability provision could have sustained a more traditional arising under analysis, see Kane, 34 Stan L Rev at 390-91 (cited in note 60), but the Court explicitly refused to rest federal jurisdiction on this provision, see Verlinden, 461 US at $496 \mathrm{n} 22$.

๘3 28 USC $\$ \$ 1604-05$ (1994).

as 28 USC $\$ 1330$ (a) (1994) (District courts are granted subject matter jurisdiction over suits against foreign sovereigns "with respect to which the foreign state is not entitled to immunity [under this Act].").

"Verlinden, 461 US at 491-97.

${ }^{65}$ See text accompanying notes 57-60. 
into citizenship under the diversity statute does not qualify as a federal ingredient.

The difference between the FSIA and the diversity statute suggests a practical test to distinguish substantive from jurisdictional issues regardless of the statutory labels. ${ }^{67}$ Substantive statutes-or statutes that are at least more than purely jurisdictional and are thus federal ingredients-supply standards that must be applied in both federal and state courts of competent jurisdiction. To test whether a statute is sufficiently substantive to qualify as a federal ingredient, a court should ask a hypothetical question: if a state court had jurisdiction over this case, would the state court have to look to federal law to resolve the dispute between the parties? ${ }^{68}$ If a state court would have to apply federal standards to resolve the dispute, then the issue is sufficiently substantive to qualify as a federal ingredient; as a federal ingredient, the statute is a constitutional exercise of arising under jurisdiction. If a state court would not have to apply the federal law to resolve the dispute, then the statute is not sufficiently substantive to qualify as a federal ingredient.

This proposed doctrinal distinction explains why the FSIA sovereign immunity standards are federal ingredients while the diversity statute is not. First, under the FSIA, the standards for sovereign immunity apply in both federal and state courts. ${ }^{69}$ As a result, if a foreign sovereign is sued in a state court, the state court must apply the federal standards as codified in the FSIA to determine whether the sovereign is immune from suit. Moreover, if a federal court dismisses a claim for lack of subject matter ju-

${ }^{7}$ See The Supreme Court, 1982 Term: Federal Jurisdiction and Procedure, 97 Harv L Rev 208, 214 (1983) (suggesting this distinction).

${ }^{6}$ Statutes granting exclusive jurisdiction to federal courts, see, for example, the Securities Exchange Act of 1934, 15 USC $\$ 78 a a$ (1994) (granting federal district courts exclusive jurisdiction over suits brought under the Securities Exchange Act), are hybrids under this test, but the test applies in this context as well. These statutes are jurisdictional in that they determine which court will hear the case, and yet, if a case within the exclusive jurisdiction of the federal courts is filed in state court, the state court must interpret federal law to dismiss the case. However, exclusive jurisdiction statutes are best understood as completely preempting state court action in specified areas. The state court does not possess subject matter jurisdiction to apply any standards in this context. Because the case could not legally be resolved in state court, the state court cannot apply federal standards to resolve the case, and therefore cannot resolve the dispute. If a state court dismisses the case for lack of subject matter jurisdiction, as it must, the dispute remains unchanged, and the parties may refile the case in federal court. Thus, to qualify as a federal ingredient, a statute must require state courts to apply federal standards to some aspect of the resolution of the dispute. The key issue is whether the case could have been filed in the proper court, whether the court was a court of competent jurisdiction. In sum, a statute granting exclusive jurisdiction to federal courts is not a federal ingredient.

${ }^{6}$ See 28 USC $\$ \S 1602,1604-05$. 
risdiction upon a finding that the sovereign is immune, that judgment constitutes a final determination regarding the issue of sovereign immunity. A private party who loses on this issue in federal court cannot refile the claim in state court, arguing that the federal court determined only the issue of federal jurisdiction and not the issue of sovereign immunity. ${ }^{70}$ In short, although the rules governing sovereign immunity determine the extent of federal jurisdiction, they also govern disputes involving foreign sovereigns in every court of competent jurisdiction. ${ }^{71}$ Because the sovereign immunity rules codified in the FSIA apply regardless of the forum, the sovereign immunity standards are a federal ingredient sufficient to sustain Article III arising under jurisdiction.

Although state courts must apply the substantive immunity standards in the FSIA, state courts will never have to apply federal diversity standards. The diversity jurisdiction statute merely grants federal courts jurisdiction over certain cases; it has no relevance for the resolution of a case in state court. While state courts must follow federal substantive laws under the Supremacy Clause ${ }^{72}$ rules that merely describe jurisdictional boundaries are not applicable in state judicial systems.

In sum, statutes are sufficiently substantive to qualify as federal ingredients when they must be applied by state courts that are competent to resolve the dispute between the parties. Although this test does not provide definitive answers to all Article III questions, ${ }^{73}$ it does provide a mechanism to identify purely ju-

"See HR Rep No 94-1487, reprinted in 1976 USCCAN at 6612 (cited in note 60).

"11 The Supreme Court's analysis of the FSIA in Verlinden provides support for this proposed doctrinal distinction. In finding that the FSIA contained a federal ingredient, the Court explicitly distinguished the FSIA from other statutes that the Court previously had found insufficient to confer federal jurisdiction. Verlinden, 460 US at 495-96. In those cases the statutes "sought to do nothing more than grant jurisdiction over a particular class of cases." Id at 496 . In contrast, the FSIA

does not merely concern access to the federal courts. Rather, it governs the types of actions for which foreign sovereigns may be held liable in a court in the United States, federal or state. The Act codifies the standards governing foreign sovereign immunity as an aspect of substantive federal law ... [and] if a court determines that none of the exceptions to sovereign immunity applies, the plaintiff will be barred from raising his claim in any court in the United States ....

Id at 496-97 (citations omitted) (emphasis added). Thus, although the standards are labeled "jurisdictional" by the statute, the Court found the standards governing sovereign immunity sufficiently substantive, in part because they apply regardless of the forum chosen by the plaintiff. Id at 497 .

${ }_{72}$ US Const, Art VI, $\mathrm{cl} 2$.

${ }^{23}$ One issue not resolved by this test was first posed in Osborn: does the federal ingredient have to appear somewhere in the case or is it sufficient that the federal ingredient be only a potential issue in the case? The debate on this aspect of Article IIIs interpretation, see note 47 , is beyond the scope of this Comment. Similarly, this test does not directly address the issue of state incorporation of federal law. If a state statute incorporates federal 
risdictional statutes without relying on the labels attached to those statutes. It separates purely jurisdictional statutes, which are insufficient to qualify as federal ingredients to sustain Article III arising under jurisdiction, from those statutes with a substantive component sufficient to qualify as federal ingredients. A statute that must be applied by state courts cannot be merely jurisdictional.

\section{The Supreme Court's arising under jurisprudence.}

This test-focusing on whether a state court of competent jurisdiction must apply federal standards to resolve the case-is consistent with the Supreme Court's arising under jurisprudence. ${ }^{74}$ The statutes upheld by the Court as consistent with Article III all contain federal standards that would have to be applied by a state court if the action were brought there. In other words, they all contain federal ingredients.

First, consider Osborn and the national Bank. ${ }^{75}$ The Court upheld the grant of federal jurisdiction under Article III because every suit by or against the Bank would necessarily involve the Bank's capacity to act. This capacity was governed by the Bank's

standards, arguably the federal standard applies regardless of the forum. However, the test proposed in this Comment is about the constitutionality of congressional grants of federal jurisdiction and whether Congress has provided (through a federal statute) that federal standards will apply regardless of the forum. When a state incorporates federal law (either by incorporating federal standards or by creating a state remedy for violation of federal standards), the state legislature has taken this action; federal standards do not apply by force of congressional action.

This interpretation of the constitutional standard arguably calls into question some of the Supreme Court's early cases suggesting that the Supreme Court has jurisdiction to review state statutes that incorporate federal law. See, for example, Smith $v$ Kansas City $T i$ tle \& Trust Co, 255 US 180 (1921); Standard Oil Co v Johnson, 316 US 481 (1942). Under the test proposed here, these cases might represent unconstitutional exercises of federal judicial power. However, the Supreme Court arguably has retreated from the positions taken in these earlier cases. See Merrell Dow Pharmaceuticals Inc v Thompson, 478 US 804, 812 (1986). Moreover, Standard Oil is perhaps best understood as Supreme Court review of a threshold question of state law necessary to protect a federal right. For an analogous exercise of federal review, see Anderson v Brand, 303 US 95, 100 (1938) (reviewing state law to determine whether there was a contract before determining whether state actions had violated the Contract clause, US Const, Art I, § 10). In Standard Oil, the Court reviewed California's conclusion that an Army Post exchange was not a federal entity and thus that a state tax on the Post exchange was constitutional. The Court reviewed the state court's determination of this issue of state law (a state law that incorporated federal law) as a threshold question necessary to protect rights guaranteed by the Constitution. Standard Oil, 316 US at $482-85$.

${ }^{74}$ This is not to suggest, however, that this test was the motivating factor behind any of the Supreme Court's decisions.

${ }^{75}$ Osborn, 22 US (9 Wheat) 738. Arguments similar to those made about the national Bank supported Article III jurisdiction in American National Red Cross v S.G., 505 US 247, 264-65 (1992). 
federal charter, which explicitly granted the Bank the ability "to sue and be sued ... in all State Courts having competent jurisdiction, and in any Circuit Court of the United States." ${ }^{.76}$ Thus, like suits under the FSIA, if a suit involving the Bank were brought in a state court, the state court would have had to apply federal law to determine if this entity-created by federal law-was capable of being sued in a state court. The federal standards governed jurisdiction of the federal courts, but they had to be applied in state courts too because the standards authorized the Bank to sue or be sued in state courts. ${ }^{77}$ To resolve the Bank's capacity to act, state courts had to apply federal law. ${ }^{78}$

This test is also consistent with Textile Workers Union $v$ Lincoln Mills. ${ }^{79}$ In Lincoln Mills, the Supreme Court upheld as a constitutional exercise of arising under jurisdiction a statute that appeared merely to grant federal jurisdiction over certain labor disputes. ${ }^{80}$ According to the Court, however, the statute went beyond a grant of jurisdiction; it also authorized federal courts to create a federal common law to govern the enforcement of collective bargaining agreements. ${ }^{81}$ Thus, the case arose under the federal substantive law to be created by the federal courts; the jurisdictional statute was not the hook for Article III jurisdiction. With federal substantive common law governing the merits of the dispute, there was no danger of bootstrapping federal jurisdiction to a purely jurisdictional statute. ${ }^{82}$

Finally, in Mesa $v$ California, the Supreme Court's interpretation of the federal officer removal statute ${ }^{83}$ to avoid Article III problems meshes with the proposed test. ${ }^{84}$ As written, the statute

is Osborn, 22 US (9 Wheat) at 817 (quoting statute).

$\pi$ The Supreme Court's bankruptcy cases display a similar pattern. Before the 1978 revision of the bankruptcy laws, the bankruptcy code permitted a bankruptcy trustee to sue in federal court for causes of action that originally belonged to the bankrupt even if those actions were based entirely on state law and there was no diversity of citizenship. See Schumacher $v$ Beeler, 293 US 367, 377 (1934). In Schumacher, the Court upheld this jurisdictional grant. Id at 374. This statute authorized suit by a federally created entity-the bankruptcy trustee-in federal courts, but it also allowed the trustee to sue in state courts. Thus, state courts would have to apply federal law to determine that the trustee could proceed with actions in place of the bankrupt. See id.

${ }_{33}$ See Carole E. Goldberg-Ambrose, The Protective Jurisdiction of the Federal Courts, 30 UCLA L Rev 542, 548-49 (1983).

${ }^{79} 353$ US 448 (1957).

¿ Id at 457 (upholding constitutionality of $\$ 301$ (a) of the Taft-Hartley Act, codified at 29 USC $\$ 185$ (1994)).

${ }^{81}$ Lincoln Mills, 353 US at 457. This interpretation of the statute is open to criticism. See id at 469-70 (Frankfurter dissenting).

$\approx$ Id at 456 (majority opinion). See also David P. Currie, Federal Jurisdiction in a Nutshell 93 (West 3d ed 1990).

${ }^{\circledast 3} 28$ USC § 1442(a) (1994).

84 489 US 121, 136-37 (1989). Technically, the Court interpreted the statute, and not 
was a purely jurisdictional statute and thus was insufficient to support arising under jurisdiction on its own. ${ }^{85}$ However, the Court interpreted the statute to require a federal officer to allege a "colorable federal defense" before the case could be removed to federal court. ${ }^{86}$ Thus, the federal defense was the required federal ingredient to sustain arising under jurisdiction. Cases removed to federal court under the federal officer removal statute arise under the substantive federal defense. If the federal officer chose not to remove the case to federal court, the state court would still have to apply federal law to adjudicate the federal defense. In sum, the Supreme Court's decisions interpreting Article III are all consistent with the proposed doctrinal test.

\section{The Westfall Act and Federal Ingredients}

The doctrinal test proposed in this Comment resolves the constitutional dilemma posed by the Westfall Act. The Westfall Act, like the FSIA, is a statute that may seem to have both substantive and jurisdictional components. After Lamagno, a federal court can review the Attorney General's certification that the employee acted within the scope of employment, but the outcome of this substantive inquiry has ramifications for the jurisdiction of the court. Is the review of the Attorney General's certification sufficiently substantive to qualify as a federal ingredient? Or is the review merely an inquiry to determine whether the court has jurisdiction to hear the case, analogous to the power of the court to determine whether parties are diverse under $\$ 1332$ ?

To resolve these questions, a court should ask whether the Westfall Act creates a federal standard that must be applied by a state court to resolve the case. In the context of the Westfall Act, a case filed in state court is a state law tort suit between two private parties, and there are no federal issues that govern the resolution of the dispute. If there is a question of federal law (scope of employment), that issue is applied and interpreted by the federal court after the case has been removed. ${ }^{87}$ The Act ensures that state courts will never have to determine whether an employee acted within the scope of employment; instead, such de-

\footnotetext{
Article III. However, its interpretation was driven in part by a desire to avoid constitutional infirmity, and so the case sheds light on the permissible scope of Article III arising under jurisdiction. See Fallon, Meltzer, and Shapiro, The Federal Courts and the Federal System at 905-06 (cited in note 8) (discussing Mesa and its implications for the scope of Article III jurisdiction).

${ }^{85}$ Mesa, 489 US at 136.

${ }^{56}$ Id at $129,136$.

${ }^{87}$ See 28 USC $\$ 2679$ (d)(2)-(3) (1994).
} 
cisions will be made by the federal court. ${ }^{88}$ The only standards necessary to resolve these cases in state courts are the standards supplied by state tort law. The Westfall Act's inapplicability in state courts means that it fails the proposed test, and it is purely jurisdictional. It is not sufficiently substantive to qualify as a federal ingredient, and cannot sustain Article III arising under jurisdiction. Thus, if the statute is interpreted to require federal courts to retain jurisdiction after they determine the employee did not act within the scope of employment, this interpretation is unconstitutional.

\section{PURPOSES OF ARISING UNDER JURISDICTION}

Not only does the test proposed in this Comment comport with the Supreme Court's treatment of federal ingredients under Article III, but it also supports the broader purposes behind Article III arising under jurisdiction. The test's distinction between federal ingredients-those federal issues sufficiently substantive to apply in both federal and state courts-and other federal issues is consistent with the two main justifications for arising under jurisdiction: (1) the need for uniformity in the interpretation and application of federal law; and (2) the vindication of federal rights. $^{89}$

\$ See Lamagno, $115 \mathrm{~S}$ Ct at 2234-35 ("The certification, removal, and substitution provisions of the Westfall Act, 28 U.S.C. $\$ 2679$ (d)(1)-(3), work together to assure that, when scope of employment is in controversy, that matter, key to the application of the FTCA, may be resolved in federal court."). Arguably, because $\$ 2679$ (d)(3) makes removal discretionary ("the action ... may be removed"), this Section allows state courts to apply federal standards if they review petitions challenging the Attorney General's refusal to certify that the employee acted within the scope of employment. However, state courts will never make these decisions. The statute states that an employee may "petition the court" and it is obvious from the context that the employee may petition a federal court. The final sentence of $\$ 2679$ (d)(3) presumes that federal courts will make this decision because it directs district courts to remand actions when they determine the employee was not acting within the scope of employment. As described above, the Supreme Court understands the statute to require that the scope of employment decision be made in federal court. Moreover, it would be inconsistent for Congress to allow this decision on federal jurisdiction to be made by state courts when the rest of the Act forces federal courts to make analogous decisions. Finally, as a practical matter, the cases will be removed regardless of the discretionary language. Research has uncovered no cases where a state court has reviewed an employee petition.

"Protective jurisdiction" theories rest on the foundation that there may be a need to protect federal rights even when federal interests are not reflected in a substantive federal statute. Professor Wechsler argued that because Congress has the greater power to enact substantive law, it can take the lesser step of merely providing for federal jurisdiction. Herbert Wechsler, Federal Jurisdiction and the Revision of the Judicial Code, $13 \mathrm{~L}$ \& Contemp Probs 216, 224-25 (1948). Professor Mishkin would allow Congress to extend federal jurisdiction to protect a congressionally enacted legislative policy. Paul Mishkin, The Federal "Question" in the District Courts, 53 Colum L Rev 157, 192 (1953). However, the Supreme Court has never upheld any exercise of jurisdiction under a theory of protective ju- 


\section{A. The Need for Uniformity in the Interpretation and Application of Federal Law}

The proposed doctrinal distinction supports the classic justification for federal jurisdiction in cases arising under federal law: the need for uniformity in the interpretation and application of federal law. Federal court interpretation of federal laws helps to ensure national uniformity. ${ }^{90}$ If the interpretation of federal laws is left to the states, multiple interpretations of such laws inevitably will develop, and the Constitution and laws of the United States will impose different obligations in different states. ${ }^{91} \mathrm{Al}-$ though the need for-and the ability of-federal jurisdiction to achieve uniformity in interpretation of federal laws can be exaggerated ${ }^{92}$ it is at least arguable that federal courts will achieve

risdiction. See Verlinden, 461 US at 491 n 17 (rejecting invitation to uphold statute under protective jurisdiction theory); Mesa, 489 US at 137-38 (same).

The most significant problem with protective jurisdiction theories is that they define the limits of federal judicial power by reference to Article I. See David P. Currie, The Federal Courts and the American Law Institute (Part I), 36 U Chi L Rev 1, 13 (1968). But to define judicial power by reference to congressional authority under Article $I$ is to destroy the limits incorporated in Article III. See text accompanying notes 50-52.

Even if these theories could justify federal jurisdiction to protect federal interests, there is no federal interest in protecting federal employees from suits when they were not acting within the scope of their employment. Although Congress might want to protect federal employees under these circumstances out of concern for hostility to federal employees, see, for example, Kenneth B. Noble, US Studies Wave of Violence in Nevada, NY Times A22 (Dec 22, 1995) (describing wave of violent attacks directed against federal officials in $\mathrm{Ne}$ vada), the need for a federal forum in this context is belied by Mesa $v$ California. In Mesa, the Court explicitly read the federal officer removal statute to require the averment of a colorable federal defense. 489 US at 129, 136-38. If the federal employee did not raise a federal defense, there was no federal interest; there was no need for a federal forum. Id at 137-38.

Finally, a concern to protect federal officers even when they are not acting within the scope of employment is belied by other provisions of the Westfall Act. Under $\S 2679$ (d)(3), an employee who petitions a denial of scope certification by the Attorney General and then loses that petition in the district court must return to the state courts. If a federal forum were necessary to protect federal employees even when they were not acting as federal employees, Congress would have required all cases against federal employees to remain in federal court.

${ }^{90}$ See American Law Institute, Study of the Division of Jurisdiction Between State and Federal Courts 165-66 (ALI 1969); Chemerinsky, Federal Jurisdiction \$ 5.2.1 at 221 (cited in note 47); Mishkin, 53 Colum L Rev at 159 (cited in note 89); Currie, $36 \mathrm{U}$ Chi L Rev at 268 (cited in note 47 ).

${ }^{91}$ See, for example, Martin $v$ Hunter's Lessee, 14 US (1 Wheat) 304, 348 (1816) ("[Without] uniformity, the laws, the treaties, and the constitution of the United States would be different in different states, and might, perhaps, never have precisely the same construction, obligation, or efficacy, in any two states. The public mischiefs that would attend such a state of things would be truly deplorable ....").

${ }^{2}$ Uniformity can be achieved through other routes, such as Supreme Court review of state court decisions. See Fallon, Meltzer, and Shapiro, The Federal Courts and the Federal System at 900 (cited in note 8). Moreover, it is not clear that multiple state court decisions will produce less uniformity than thirteen federal courts of appeals. See Chemerinsky, Fed- 
more uniformity in the interpretation of federal laws than state courts. ${ }^{93}$

Although uniformity of interpretation is necessary when Congress creates federal substantive law, it is unnecessary when there is no federal law to interpret. The Westfall Act demonstrates this distinction. Congress has a federal interest in uniform interpretation of whether an employee was acting within the scope of employment. The statute promotes this interest by providing for federal court determination of this issue. ${ }^{94}$ If a federal court decides that the employee was not acting within the scope of employment, only a state tort suit remains, and the federal interest in uniformity drops out. Thus, Congress has an interest in uniform jurisdictional inquiries, and those inquiries are made in federal court. Similarly, because there is no uniformity interest in the interpretation of state tort law, those issues can be resolved in state court.

\section{B. Vindication of Federal Rights}

The test proposed here also supports the second major justification for federal jurisdiction: federal jurisdiction provides a forum for the vindication of federal rights. ${ }^{95}$ The Constitution provides Congress with the flexibility to establish federal jurisdiction over federal claims when Congress decides that it cannot trust state courts to enforce fully rights created by the federal government. Perhaps state courts will view federal rights narrowly ${ }^{96}$ or

eral Jurisdiction $\$ 5.2 .1$ at 221 (cited in note 47 ).

${ }^{53}$ See, for example, American Law Institute, Study of the Division of Jurisdiction at 165-67 (cited in note 90) (noting that federal courts may be more amenable to guidance from the Supreme Court and suggesting that the selection process for federal judges may contribute to uniformity of decisions).

${ }^{*}$ See 28 USC $\$ 2679(d)(2)$-(3) (providing for removal of actions to federal court whenever jurisdictional issue is contested). At first glance, the absence of a similar remand provision under $\$ 2679(\mathrm{~d})(2)$, when the court rejects an initial Attorney General certification, might suggest that this inquiry is more than jurisdictional. One potential explanation for this inconsistency is that Congress never intended for the Attorney General's certification to be reviewable. Under this reading, once the Attorney General decided the employee acted within the scope of her employment, the case was to proceed against the United States under the FTCA. Because a court could not reject this certification, there was no need for a remand provision. See Lamagno, $115 \mathrm{~S} \mathrm{Ct}$ at 2240 (Souter dissenting). However, the Supreme Court rejected this interpretation of the statute in Lamagno. Id at 2234-36 (Ginsburg plurality opinion).

${ }^{55}$ See Currie, 36 U Chi L Rev at 268 (cited in note 47); American Law Institute, Study of the Division of Federal Jurisdiction at 167-68 (cited in note 90). See also Mishkin, 53 Colum L Rev at 159 (cited in note 89) (" $[\mathrm{I}) \mathrm{t}$ is desirable that Congress be competent to bring to an initial national forum all cases in which the vindication of federal policy may be at stake.").

${ }^{56}$ See Wechsler, $13 \mathrm{~L} \&$ Contemp Probs at 233-34 (cited in note 89); Fallon, Meltzer, and Shapiro, The Federal Courts and the Federal System at 901 (cited in note 8). 
will not review them with the appropriate sympathy. ${ }^{97}$ Federal judges, who are chosen and paid by the federal government, are more likely than state judges to give full force to Supreme Court decisions and acts of Congress, especially when those decisions or actions are unpopular locally. ${ }^{98}$

The Westfall Act demonstrates that when Congress establishes substantive federal standards, a federal forum ensures those standards are fully vindicated, but that when Congress passes a mere jurisdictional statute, there is no need for a federal forum. Federal courts may always determine whether they have jurisdiction over a case and this interest is explicitly vindicated in the Westfall Act. ${ }^{99}$ In contrast, if the court concludes that the employee was not acting within the scope of employment, the substantive rights at issue are fully governed by state law. There is no danger of narrow or hostile interpretations of federal law. Following a federal inquiry into the scope of employment, and a finding that the employee did not act within the scope of employment, there is no federal interest in retaining the case.

\section{THE ANALOGY to SUPPLEMENTAL JURISDICTION}

This Comment has proposed a test to help courts determine whether the Westfall Act-or any other statute-is sufficiently substantive to sustain Article III arising under jurisdiction. Thus, this test moves beyond the conclusory statements of both the plurality and the dissent in Lamagno as to what does or does not constitute a federal ingredient.

However, Justice Ginsburg's plurality suggested a potential challenge to the resolution proposed by this Comment. She implied that the Westfall Act might survive constitutional scrutiny through an analogy to supplemental jurisdiction. ${ }^{100}$ She argued that because a federal issue at the initial stages of the litigationthe review of the Attorney General's certification-would overlap factually with the merits of the tort claim, considerations of judicial economy and fairness that underlie supplemental jurisdiction suggest that the court should continue adjudicating the case. ${ }^{101} \mathrm{In}$

\footnotetext{
${ }^{97}$ See Chemerinsky, Federal Jurisdiction $\$ 5.2 .1$ at 221 (cited in note 47). See also James H. Chadbourn and A. Leo Levin, Original Jurisdiction of Federal Questions, $90 \mathrm{U}$ Penn L Rev 639, 648 (1942); Currie, 36 U Chi L Rev at 269 (cited in note 47).

${ }^{23}$ See American Law Institute, Study of the Division of Jurisdiction at 167 (cited in note 90); Mishkin, 53 Colum I Rev at 158 (cited in note 89).

28 USC \& 2679(d)(2)-(3).

${ }^{100}$ The modern doctrine of supplemental jurisdiction is derived from United Mine Workers $v$ Gibbs, 383 US 715 (1966), and is now codified in 28 USC $\$ 1367$ (1994).

${ }^{101}$ Lamagno, $115 \mathrm{~S}$ Ct at 2237, quoting Gibbs, 383 US at 725.
} 
other words, Ginsburg argued, the Westfall Act's requirement that federal courts retain federal jurisdiction over state law tort claims is constitutionally justified on the same policy grounds as those supporting supplemental jurisdiction. Just as Congress has the constitutional power to allow supplemental jurisdiction, ${ }^{102}$ Congress has the power to allow this exercise of jurisdiction under the Westfall Act.

Justice Ginsburg's invocation of supplemental jurisdiction principles was an analogy based on overlapping policy considerations; this is not a case for the direct exercise of supplemental jurisdiction. In the normal supplemental jurisdiction case, there are two claims (one state and one federal), and the question is whether the federal court may exercise jurisdiction over the state law claim. Under the Westfall Act, there is only one claim (a state law tort claim) coupled with a jurisdictional inquiry about whether that claim should be heard in federal court. There is no separate federal claim for the state claim to supplement. ${ }^{103}$ Thus, to justify the exercise of federal jurisdiction under the Westfall Act by analogy to supplemental jurisdiction, the same policies underlying supplemental jurisdiction should be in operation here. However, the policies underlying supplemental jurisdiction do not support the exercise of jurisdiction contemplated by the Westfall Act.

\section{A. Judicial Economy}

A primary justification for supplemental jurisdiction is practical: federal courts should decide factually related state law claims because such decisions will conserve judicial resources, and will be more convenient for and fair to the parties. ${ }^{104}$ If the same facts and evidence support both claims, common sense argues for the federal court to decide the state law claim once it has considered the same facts and evidence to decide the federal issues. If the court declines to decide the state issues, the state claim must be relitigated in state court and a new judge and/or jury will have to digest and decide the issues and evidence. Repe-

\footnotetext{
${ }^{102}$ The supplemental jurisdiction statute-with few exceptions-authorizes courts to exercise jurisdiction over claims up to the constitutional limit on cases or controversies in Article III. See Denis F. McLaughlin, The Federal Supplemental Jurisdiction Statute-A Constitutional and Statutory Analysis, 24 Ariz St L J 849, 890-91 (1992).

${ }^{103}$ As one observer noted, the retention of a state claim after the district court determines that there is no federal claim "bears no resemblance to any statutory scheme with which we are familiar." Brief of Michael K. Kellogg, Amicus Curiae Supporting the Judgment Below at n 18, Lamagno, $115 \mathrm{~S} \mathrm{Ct} 2227$ (1995).

${ }^{1 M}$ Gibbs, 383 US at 726. See also Carnegie-Mellon University $v$ Cohill, 484 US 343, 349 (1988).
} 
tition of this nature increases costs, wastes resources, and raises the risk of inconsistent verdicts in the two fora. ${ }^{105}$ Given this potential savings of substantial resources, the intrusion on states' rights caused by supplemental jurisdiction seems less troubling. ${ }^{106}$

In Lamagno, both the plurality and the dissent assumed that there would be overlap between the factual evidence regarding the employee's scope of employment and the evidence regarding the alleged tortious acts. ${ }^{107}$ This substantial overlap motivated Justice Ginsburg's invocation of the supplemental jurisdiction analogy. ${ }^{108}$ However, it is not obvious that the evidence regarding the employee's scope of employment always will overlap significantly with the evidence regarding tort liability. Under the FTCA, scope of employment is to be determined by state law standards of respondeat superior. ${ }^{109}$ Although state laws will vary, the Restatement (Second) of Agency states that conduct is within the scope of employment if (1) it is conduct the employee is employed to perform; (2) it occurs substantially within the time and space limits of employment; (3) it is actuated at least in part by a purpose to serve the employer; and (4) if intentional force is used, the use of such force is not unexpected by the employer. ${ }^{110}$ These criteria suggest that there may be overlap between the inquiry into

\footnotetext{
${ }^{105}$ See Chemerinsky, Federal Jurisdiction $\$ 5.4 .1$ at 276 (cited in note 47); Currie, Federal Jurisdiction in a Nutshell at 106 (cited in note 82). See also Wechsler, $13 \mathrm{~L}$ \& Contemp Probs at 232 (cited in note 89) (noting that there is a "vice" in forcing plaintiffs to pursue actions in different courts at different times).

${ }^{106}$ See Currie, 36 U Chi L Rev at 281 (cited in note 47 ).

${ }^{107}$ Lamagno, $115 \mathrm{~S}$ Ct at 2237; id at 2240 (Souter dissenting). See also Roland B. Ninomiya, Casenote, Under the Westfall Act, A Plaintiff Can Obtain Judicial Review of the Attorney General's Certification That the Defendant-Employee was Acting within the Scope of her Employment: Gutierrez de Martinez v. Lamagno, 4 Geo Mason L Rev 485, 516 (1996) (asserting that "[a] near total overlap in [the] two inquiries is unavoidable").

${ }^{108}$ Lamagno, $115 \mathrm{~S} \mathrm{Ct}$ at 2237.

${ }^{109}$ See 28 USC § 1346(b) (1994). See also Haddon v United States, 68 F3d 1420, 1423 (DC Cir 1995) (noting that scope of employment is to be determined by the law of the location of the tort); Aliota $v$ Graham, 984 F2d 1350, 1356 (3d Cir 1993) (same); Jamison v Wiley, 14 F3d 222, 237 (4th Cir 1994) (same). Thus, federal courts apply state law to determine whether they have jurisdiction over the suit (that is, to determine whether the employee was within the scope of employment). Moreover, because the Westfall Act ensures that state courts will never resolve this state law issue, see note 88 , the federal court determination of scope of employment is binding on state courts. However, the only binding effect of this issue is whether the United States is a party and thus whether there is federal jurisdiction. The state court will apply state law to resolve the underlying tort suit.

${ }^{110}$ Restatement (Second) of Agency $\S 228(1)$ (1938). See Haddon, 68 F3d at 1423-24 (noting that the District of Columbia follows the Restatement); Aliota, 984 F2d at 1358 (noting that Pennsylvania would likely follow the Restatement); Garcia v United States, 88 F3d 318, 320-21 (5th Cir 1996) (noting factors considered by Texas courts and listing factors similar to Restatement); Jamison, 14 F3d at 237 (noting factors of Virginia law similar to Restatement). See also W. Page Keeton, ed, Prosser and Keeton on the Law of Torts $\$ 70$ (West 5th ed 1984).
} 
scope of employment and the inquiry into the allegedly tortious conduct. ${ }^{111}$

However, it seems likely that in other cases, there will not be a substantial factual overlap between the two inquiries. For example, in Haddon $v$ United States, a White House electrician allegedly threatened to "beat up" a White House chef. ${ }^{112}$ The D.C. Circuit considered the electrician's employment duties, and the conduct that might be warranted in the performance of these duties. The court's inquiry did not require an analysis of the allegedly tortious acts. ${ }^{113}$ Similarly, in Johnson $v$ Carter, an Admiral was sued for libel after disciplining a military base police officer, and the Fourth Circuit held that the Admiral's disciplinary activities were within the scope of his employment. ${ }^{114}$ The court reached this conclusion following a review of actions the Admiral previously had taken to promote discipline, and a review of the Navy Regulations that dictate when an Admiral is acting as a naval officer. ${ }^{115}$

Thus, although there may be some factual overlap between the inquiries into scope of employment and the allegedly tortious conduct, this overlap will not always be present. The argument for an analogy to supplemental jurisdiction is far weaker without this factual tie.

\section{B. Avoid Deterring Federal Claims}

A Westfall Act analogy to supplemental jurisdiction also fails to find support because there is no danger of deterring federal claims. The exercise of supplemental jurisdiction avoids deterring plaintiffs from bringing meritorious federal claims in federal court

\footnotetext{
${ }^{\prime \prime \prime}$ For example, in Aliota $v$ Graham, a defendant was accused of defaming the plaintiff, and the inquiry into scope of employment compared the allegedly tortious statements made by the defendant with the types of statements she was authorized to make by her employer. 984 F2d at 1359. See also Nadler v Mann, 951 F2d 301, 305-06 (11th Cir 1992) (comparing job responsibilities of Assistant United States Attorney with his allegedly tortious actions in investigating a crime to determine whether his actions were within the scope of his employment).

${ }^{112} 68$ F3d at 1422.

${ }^{113}$ Id at 1423-25.

${ }^{14} 983$ F2d 1316, 1317-19, 1322-23 (4th Cir 1993) (en banc).

${ }^{115}$ Johnson, 983 F2d at 1322-23. Other courts have addressed "scope of employment" without having to consider the allegedly tortious conduct. See Garcia, 88 F3d at 320-21 (evaluating federal employee's duties and typical job description to determine whether the employee was on a "special mission" for the employer when he was involved in a car accident); Dillon v Mississippi, 827 F Supp 1258, 1262-64 (S D Miss 1993) (considering defendants' assigned duties and compensation system to determine whether the defendants were acting within the scope of their employment when several soldiers were injured during a training mission).
} 
and thus preserves the attractiveness of the federal forum. ${ }^{116}$ If all claims cannot be heard in federal court, the plaintiff could bring the federal claim in federal court and the state claim in state court. Pursuit of two similar claims in two different courts is expensive and time consuming, and the plaintiff's second claim may be barred by doctrines such as res judicata or collateral estoppel. ${ }^{117}$ Alternatively, the plaintiff could choose to abandon her state claim and to pursue the federal claim in federal court. Such a result is unfair to plaintiffs with meritorious state law claims. ${ }^{118}$ The plaintiffs final alternative, if denied supplemental jurisdiction, is to proceed in state court on both the federal and state claims. This option deprives the plaintiff of a federal forum in which to vindicate her federal rights. ${ }^{119}$ Thus, without supplemental jurisdiction, the federal forum is a less attractive forum for a plaintiff who has both federal and state claims.

Unlike the incentives and deterrents at work in the supplemental jurisdiction context, in cases under the Westfall Act it seems unlikely that a plaintiff will be deterred from bringing a meritorious federal claim in federal court. In a typical FTCA case, the plaintiff may bring the state law tort claim in state court, and no companion federal claims exist to be deterred by the unavailability of a federal forum. It is unproblematic to force plaintiffs with only state claims to have them heard in state court. Because there is no federal claim to fear deterring, the analogy to supplemental jurisdiction policies fails.

\section{Federalism Interests}

Finally, the same federalism concerns that counsel against the exercise of supplemental jurisdiction also counsel against the exercise of jurisdiction contemplated by the Westfall Act. Federalism interests weigh against the exercise of supplemental jurisdiction because a federal court decision on state law claims necessarily intrudes on the domain of state courts. In ordinary cases of supplemental jurisdiction, judicial economy and a desire to avoid deterring federal claims justify the intrusion into state law. ${ }^{120}$ However, federal adjudication of state law claims is disadvantageous. The federal courts cannot authoritatively interpret state

\footnotetext{
${ }^{116}$ See Chemerinsky, Federal Jurisdiction $\S 5.4 .1$ at 276 (cited in note 47); American Law Institute, Study of the Division of Jurisdiction at 209 (cited in note 90).

${ }^{117}$ See McLaughlin, 24 Ariz St L J at 863 (cited in note 102). See also American Law Institute, Study of the Division of Jurisdiction at 209 (cited in note 90).

${ }^{118}$ See McLaughlin, 24 Ariz St L J at 863 (cited in note 102).

${ }^{119}$ Id at 863-64.

${ }^{120}$ See Currie, 36 U Chi L Rev at 281 (cited in note 47 ).
} 
law. Furthermore, since there is no mechanism for state courts to review errors made by federal courts in their interpretation of state law, such errors cannot be corrected. ${ }^{121}$ Thus, an important consideration with respect to the proper scope of federal jurisdiction is the "general desirability of state court decision of state law issues,"122 and under the supplemental jurisdiction statute, federal courts must consider the interests of comity and federalism in their decisions on whether to exercise supplemental jurisdiction over state law claims. ${ }^{123}$

The federalism concerns at work in supplemental jurisdiction decisions have special force in the Westfall Act context. When the federal court decides that the employee was not acting within the scope of her employment, the court is left with a state law tort claim. The federal court cannot authoritatively interpret state law, and any decision it makes on the state issue intrudes on state autonomy. Federalism concerns are especially important when the interest in judicial economy may be weak and there is no danger that plaintiffs will be deterred from bringing federal claims. In sum, the policies underlying the exercise of supplemental jurisdiction do not support the exercise of jurisdiction contemplated by the Westfall Act. Justice Ginsburg's analogy is not persuasive because concerns for judicial economy may be weak, there is no danger of deterring federal claims, and federalism concerns counsel against the exercise of this jurisdiction by federal courts.

\section{CONCLUSION}

The Westfall Act is the latest statute to test the frontiers of the Article III arising under boundary. Although the Supreme Court has established that a statute must contain a federal ingredient to sustain Article III arising under jurisdiction, the Court has never provided a test to determine when a statute is sufficiently substantive to qualify as a federal ingredient. This Comment fills this gap by suggesting a functional test: a statute is sufficiently substantive to qualify as a federal ingredient when a state court of competent jurisdiction would have to apply federal standards to resolve the case.

\footnotetext{
${ }^{121}$ See Wechsler, 13 L \& Contemp Probs at 232 (cited in note 89).

${ }^{122}$ Mishkin, 53 Colum L Rev at 165 (cited in note 89). See also the comments by Justice Frankfurter in a different context: "Any advantage of giving jurisdiction to the federal courts must be balanced against the disadvantages of taking away from the State courts causes of action rooted in State law." Williams $v$ Austrian, 331 US 642, 680 (1947) (Frankfurter dissenting).

${ }_{1 \approx 2}^{12}$ See 28 USC $\$ 1367(c)(1)-(3)$ (1994). See also McLaughlin, 24 Ariz St L J at 977-78 (cited in note 102).
} 
As the Westfall Act was interpreted in Lamagno (to require federal courts to retain jurisdiction over state law tort claims), the Westfall Act is unconstitutional because state courts do not have to apply federal standards to resolve state law tort suits. Moreover, contrary to Justice Ginsburg's suggestion in Lamagno that federal jurisdiction might be justified by an analogy to supplemental jurisdiction, this analogy does not support the exercise of jurisdiction under the Westfall Act because the policies underlying supplemental jurisdiction do not similarly underlie the Westfall Act. Thus, the exercise of jurisdiction contemplated by the Westfall Act is unconstitutional, and federal courts should interpret the Westfall Act to require remand of state law tort suits to state courts. ${ }^{124}$ By remanding state law tort claims between private parties to state courts, federal courts will exercise only that judicial power expressly granted by Article III.

${ }^{122}$ See Haddon, 68 F3d at 1427. 